\title{
Spermatid Nuclear Transition Protein 1
}

National Cancer Institute

\section{Source}

National Cancer Institute. Spermatid Nuclear Transition Protein 1. NCI Thesaurus. Code C106294.

Spermatid nuclear transition protein 1 ( $55 \mathrm{aa}, \sim 6 \mathrm{kDa}$ ) is encoded by the human TNP1 gene. This protein is involved in the maturation of sperm. 